\title{
Role of Emotional Intelligence and Work-Life Balance in Relationship between Workplace Happiness and Perceived Performance in Academic Setting*
}

\author{
Tayfun ARAR ${ }^{1} \odot$, Melahat ÖNEREN ${ }^{2} \odot$
}

\begin{abstract}
This study was conducted to confirm the thesis of "happy employee=productive employee" in an academic setting in which the working hours and workplace is not as clear as in other workplace settings that the aforementioned thesis was handled in. Thus, the pioneer aim was to investigate the relationship between workplace happiness and perceived academic performance. Based on the possible relationship, it was to analyze the moderator effect of emotional intelligence and mediator effect of work-life balance with sub-dimensions respectively. The study was conducted in 42 universities locating in Central Anatolia Region of Turkey with 1136 academicians. In analyzing data, hierarchical regression analysis was conducted. The results showed that workplace happiness positively affected perceived academic performance directly. Moreover, this effect became stronger with emotional intelligence and its three sub-dimensions. Besides, three sub-dimensions of worklife balance partially mediated this relationship. This research make theoretical contributions to literature by validating the thesis also in academic setting and the mediating role of work-life balance, opposite to that of the literature. It also has some practical contributions to universities by showing how to improve performance.
\end{abstract}

Keywords: Workplace Happiness, Perceived Academic Performance, Emotional Intelligence, Work-Life Balance JEL Codes: 123, M10, M12

\section{Introduction}

Knowledge has been the most crucial value to societies so far. We consider societies as developed if they proactively produce, access, and practically use knowledge. In this context, universities are prominent organizations in which knowledge is produced and transferred via research and teaching processes (Houston, Meyer and Paewai, 2006). Universities play substantial roles in shaping societies' future by raising competent generations and doing scientific researches through academicians (Rowley, 1996) who mostly use their intelligence by curiosity. By working with high performance, they take responsibility for raising the human resources necessary for the changes and developments in the society (Gür, 2017). This performance includes scientific research and publication, education activities, and administrative services in order of importance (Houston et al., 2006). Turkey has made progress in academic performance (AP) recently, but principally it is still not in a position qualitatively desirable. The reasons lie behind this problem could be classified into three periods. The first period, which had lasted until 1989 , constituted left wing-right wing conflicts, political instability, and difficulty of conducting scientific research in a country with relatively poor socio-economic conditions. Second period began in 1993 with one of the well-established universities' rector assistant's speech which claimed that universities were notably converted into education institutes for mass instead, they were expected of serving elitist education (Ak and Gülmez, 2006). Since this speech, it was understood that most universities in Turkey had grown away from scientific research and focused on educating an incre-

\footnotetext{
*This study is based on the PhD dissertation titled as "Akademide İşyeri Mutluluğu İle Performans Arasındaki İlişkide İş Yaşam Dengesi Ve Duygusal Zekânın Rolü" written by Tayfun Arar and supervised by Melahat Öneren in Kırıkkale University Institute of Social Sciences.

${ }^{1}$ Arş. Gör. Dr., Kırıkkale Üniversitesi, İşletme Bölümü, İktisadi ve İdari Bilimler Fakültesi, Kırıkkale/Türkiye, tayfunarar@kku.edu.tr

${ }^{2}$ Doç. Dr., Kırıkkale Üniversitesi, İ̧letme Bölümü, İktisadi ve İdari Bilimler Fakültesi, Kırıkkale/Türkiye, melahatonerenn@gmail.com
} 
asing number of students and social problems. In third phase, with government intervenes, the number and scales of universities increased in 10 years exceedingly as a counter policy to other G20 countries (Uyar, 2018). Apart from these, the established research culture, foreign language problem, heavy course loads, and insufficient funds reserved for scientific research lead to this problem.

In terms of quantitative statistics, we see that there is a rising trend in the numbers of Turkey-based publications indexed in both SCOPUS and WoS recently (Bibliometric Analysis, 2020). However, according to the same database, the number of publications per million-people decreases. According to Ertekin (2014), $40 \%$ of those publications are not cited. Besides, there are only 11 universities in "The World" index, 1 in "ARWU" index, and 10 in "QS World" and "URAP" indexes (Olcay and Bulu, 2016) on a study conducted when there were 193 universities, which reveals the insufficiency of AP. According to Göksu and Bolat (2017), Turkey is still far from its ideal academic position, and the universities would not compete with their rivals in U.S. and Europe. This situation motivated researchers to investigate how to improve AP. Talent, energy, creativity, motivation, ambition, self-discipline level (Wood, 1990), scientific skills, predisposition to technology, language skills, self-efficacy, gender (Gür, 2017), age (Kyvik and Olsen, 2008), academic optimism, emotional intelligence (EI) (Bozkurt and Ercan, 2017), career capital and self-consciousness (Aytekin, Erdil, Erdoğmuş and Akgün, 2016) have been analyzed as individual, while fund, equipment and tenure provided (Wood, 1990), perceived empowerment (Çöl, 2008), information sharing in-house (Ghabban, Selamat and Ibrahim, 2018), competition level in-house (Saydan, 2008), administrative work-loads (Gür, 2017) have been studied as organizational factors. Incentive policies and applications (Masron, Ahmad and Rahim, 2012), salary and additional charges (Argon, 2010) as environmental and job-related factors have been analyzed so far. Despite those factors, there is another term, which is workplace happiness (WPH) that has been popular in the last two decades, haven't been studied in regards of its impact on AP yet. It is defined as the workplace situation in which the employees work happily, efficiently, and reach both individual and organizational purposes easily (Januwarsono, 2015). In the literature, there has been a thesis of "happy employee $=$ productive employee" since Hawthorne studies (Wright and Cropanzano, 1997), which is still popular as "Holy Grail" in the management field (Quick and Quick, 2004) claiming that if the employees are happy, they are more productive (Fisher, 2010). The logic behind is that happiness extends employees' interest, cognition and actions, forms their physical, intellectual and social capitals while reducing their stress levels and encouraging them for social affairs (Rego and Cunha, 2008). Happiness enables employees to perceive their jobs more meaningfully (Rego, Ribeiro and Cunha, 2010). For Bakker and Oerlamans (2011), happy employees are more energetic, sympathetic, open and more determined when facing a difficult situation. These employees receive more support from their colleagues and supervisors due to their positive mood and their help in advance (Rego and Cunha, 2008). As the studies, which examined this thesis, are analyzed, we see that they either addressed the issue theoretically (Lyubomirsky, King and Diener, 2005; Boehm and Lyubomirsky, 2008) or the work-fields dealt are framed by concrete office-hours taking place at only workplace such as schools (Tadic, Bakker and Oerlemans, 2013) and private companies (Rego and Cunha, 2008; Januwarsono, 2015). But in academia, office hours are relatively flexible. Moreover, an academician works not only during office hours at workplace but anywhere available (Fontinha, Easton and Laar, 2019). Furthermore, this thesis works accurately in jobs that require creativity. For jobs those are composed of routine tasks and strict rules to follow, WPH distracts the employees and results in hesitation which leads decreasing in performance. In Turkey, especially research assistants and other lecturers who are charged with administrative duties are spending their office hours with administrative tasks which are mostly routine and require strict rules instead of academic issues (Wood, 1990). In this regards, it is not clear if WPH has a positive effect on AP. For these reasons, this study revisits this thesis to validate in academic setting. But in this research, instead of objective performance measurements, the perceived academic performance (PAP) was taken into consideration. We supposed that it would not make any difference since perceptional and objective assessment would be equal because an academician is expected to be physically and mentally healthy and rationale. In this possible positive effect, $\mathrm{El}$, which is a must for an academician, was to be examined if it moderates the relationship. Academia requires technical information in terms of cognitive intelligence $(\mathrm{Cl})$ as well as requiring $\mathrm{El}$ due to its social nature. In communicating with students, supervisors and colleagues in terms of education, administrative duties and collaborated scientific research respectively, academicians should control and manage their emotions (Mustafayeva and Ustun, 2018). In this research, 
moderator effect of El was discussed in two ways, one of which is also divided into two segments. First is academicians who perform mostly administrative duties during office hours because these kind of duties are generally routine and the effect of WPH on PAP may be negative, so that they should control their emotions in order not to reflect the level of happiness negatively on PAP. Second one is about the facts that because universities are socio-technical sites and have academicians of different characters, who desire or reach the highest point in Maslow's hierarchy of needs, the competitive environment, emotional fatigue, fragility, and sadness may cause various negative emotions. It is important to control and direct these emotions in order not to affect the PAP in conducting research and teaching activities. The second way would be the situations when the academicians are happy at work in activities that require creativity, the effect of this situation on their performances would increase exponentially via El.

Apart from the direct effect, the indirect effect of WPH on PAP via work-life balance (WLB) was also examined. Based on the model developed by Greenhaus, Collins and Shaw (2003) claiming that all sources should be divided into work and life equally, and on the idea that if academicians are happy at work, they will spend more time at work which leads to higher performance, at least by perception of it, by decreasing WLB. Although in literature, when provided WLB is said to lead to higher performance, in this study, the reverse logic was to be analyzed, along with supporting the original idea. That means WLB may contribute to higher performance; nevertheless, in this WPH and PAP relationship, WLB was expected to play a partial mediating role in the reverse sense.

\section{Contextual Framework}

\section{Workplace Happiness}

WPH is defined as experiencing positive emotions towards work frequently and negative ones rarely (Singh and Aggarwal, 2018). Happiness dates back to Aristoteles, 2000 years ago, and was first addressed by philosophers who approach it in two ways as eudemonism and hedonism (Fisher, 2010). Because of it's referring to self-development, virtue, and being useful for others (Ryan and Deci, 2001), eudemonism would be more valid for academicians. Psychology which has dealt with problematic issues for years (Diener and Seligman, 2002), such that according to Diener, Suh, Lucas and Smith (1999), the ratio of negative topics studied to positive ones was found as 17:1, took over happiness from philosophers with Seligman (2000) who initialized the term "positive psychology" and emphasized that positive topics should be studied more. The ratio motivated Luthans in 2002 to do a similar research to emphasize the need for positive organizational behavior (POS). So of such a ratio, 375:1, even he put forward POS (Wright, 2003) including happiness, WPH has been started to be studied especially in early 2000s by researchers such as Lyubomirsky et al. (2005) and Fisher (2010). Throughout this process, researchers used other terms instead of WPH such as job satisfaction, flow, and organization commitment which have narrower coverage compared to WPH (Fisher, 2010).

\section{Perceived Academic Performance}

AP is defined as the value of the academician by examining various criteria together (Gür, 2017) such as scientific research quality and frequency, teaching activities and administrative duties. PAP is determined by the perception of an academician on one's self performance. They are expected to be parallel from such a rational and mental healthy person. AP is primarily performed in universities which are indispensable for developed societies because of their position and are digested by their institutional environment because of the complexity (Houston et al., 2006) and technical uncertainties in their organizational structures and the difficulties in performance measurement (Ünal, 2017). The reason for this is that it is not precisely certain which activities they should focus on more. In this context there are two different viewpoints in academia in Turkey. First one, called as "scientific logic" refers to aiming at producing knowledge under universal principles and scientific methods, while the second one, called as "local logic" that refers to serving of knowledge, which is already obtained, for the development purpose by adapting it in the country (Ünal, 2017). Unfortunately, instead of integrating the two logics, preferring only one because of the various degrees of importance within the scope, the development of academia becomes difficult.

\section{Emotional Intelligence}

As controlling one's self and others' emotions, distinguishing between them and using the information obtained throughout the process in others' thoughts and actions (Salovey and Mayer, 1990), El has changed humanity and the world's perspective, with the realization that feelings, which were seen as insignificant in the years when classical management was dominant and even prevent people from their goals (Alici and 
Yılmaz, 2017). It provided many professional and personal benefits, as they were developed and used with excellent education later. The roots of El based on Thorndike's Social Intelligence theory in 1920 (Tischler, Biberman and McKeage, 2002), but the term was first brought in literature by Mayer and Salovey in 1990 and in Goleman's book in 1995 drew the business world's attention by relating it to job performance (Baba, 2017). Because of the nature of the profession, academicians need technical knowledge and human relations. They use $\mathrm{Cl}$ mostly in the technical part and El in the social context. The importance attributed to $\mathrm{Cl}$ for years has been replaced recently by El (Goleman, 2007) because it can be improved and it plays a greater role in success (Slaski and Cartwright, 2003).

\section{Work-Life Balance}

Two essential models lead to different understanding of WLB. Guest (2002) defends the opinion that WLB is the perceived balance between private life and work-life, which means sources should be divided optimally as far as satisfying all needs while Greenhaus et al. (2003) claim that the sources (time, commitment, and satisfaction) of oneself should be divided into private life and work-life equally. WLB was first used in practical life in the 1930 s by Kellog Company in shifting (Korkmaz and Erdoğan, 2014) and then in literature 30 years later in 1965 with Rapoport and Rapoport (Nizam and Kam, 2018). Increasing demands in both family and work-lives (Oyewobi, Oyekunle, Adeneye and Jimoh (2019) and increasing competition made the sources (energy and time) of humans insufficient (Foy, Dwyer, Nafarrete, Hammoud and Rockett, 2018). Along with this, women's increasing education level and participation in business life escalated the number of double-careers couples (Karkoulian, Srour and Sinan, 2016) which changed family structures. Despite the bad course of the global economy, human desires of consumption and for the better have put the decline in births and the families in danger. As women gained their economic freedom, divorces increased and the general demographic structure started to deteriorate (Doğrul and Tekel, 2010). Today, maintaining WLB, which academicians have difficulty with (Fontinha et al., 2019), is important for both individuals, families, companies and governments because of these developments.

\section{Literature Review and Hypotheses Developing}

\section{WPH and PAP}

Since Hawthorne studies, the thesis of "happy employee = productive employee" has been tested in various studies based on different sectors in the literature, and mostly a positive relationship was found between the two variables. Supporting this, Yılmaz (2013) states WPH as one of the items while listing the common features of high performance organizations. According to Ardıç and Erbaşaran (2019), while turnover rates of happy employees are lower; job satisfaction, motivation, and performance levels are higher. Wright and Cropanzano (2007) explain the relationship between WPH and performance in a logical framework, regarding how the performance of unhappy employees will be negatively affected. According to the study, unhappy employees are more sensitive in the face of negative events, perceive uncertainties threatening, see negative reviews more destructive, and benefit less from positive feedback. These have devastating consequences for their performance. This situation happens more often in professions that require human interactions, such as academics. Unhappy people are more careful in social situations, introverted and prone to shyness. This causes them to adopt a hostile attitude and use tactics for discussion, and this condition can anger their colleagues and superiors. This situation complies with the complaint of unhappy employees that there is little support from their colleagues and supervisors. Apart from this, one of the most significant factors in increasing the performance of employees is their motivation. According to Herzberg's theory, the factors that increase motivation are divided into two groups as internal and external (motivator-hygiene factors). In the workplace, the physiological and sociological factors that make the employees happy are included in the external factors. In other words, WPH as an environmental and social factor counted as a hygiene factor affects motivation. Therefore, it increases the performance. Relevantly, Argon (2010) stated that working environment and qualifications affect the performance of employees. Similarly, Bozkurt and Ercan (2017) emphasize the physiological and psychological factors in the work environment affect AP. In Wood's (1990) study, he stated that the characteristics of the work environment and attitude and behaviors of colleagues affect AP. This study conceptually explains WPH can affect $A P$, yet any empirical study in the literature does not exist to support this claim. In addition, while Turkey is in $41^{\text {st }}$ position among 45 countries in the 
world ranking in terms of happiness index; it is ranked $20^{\text {th }}$ of 32 countries in terms of reference publications, self-citations, citations per publication and academic performance context (Ortaş, 2018). In this respect, the first two hypotheses to be examined within the scope of the research are:

$\mathrm{H}_{1}$ : Positive relationship exists between WPH and PAP.

$\mathrm{H}_{2}:$ WPH positively affects PAP.

\section{WPH, El and PAP}

According to Tarhan (2014), there are two basic steps for a person to attain happiness. First is that the being aware of oneself, recognizing, directing and acting with the help of one's emotions, while the second is communicating with other people and being able to recognize other party's emotions. According to the same study, he defined the emotional qualities required for happiness and success as El. In addition, we should not forget that emotions play a substantial role in human beings of modern life, and general intelligence increases as El develops (Balanescu, 2018), and ultimately, intelligence affects performance positively. According to the study of Ince, Gül and Gözükara (2015), El makes it easier to deal with work pressure and stress and provides a better work life to the person. Similarly, for Bozkurt and Ercan (2017), the level of El is among the factors affecting the employee performance, as well as other physiological and psychological factors. According to the same study, while these physiological and psychological factors that cause stress affect individual performance negatively, people with El are expected to transform their positive thoughts into high performance or to control emotions and thoughts that negatively affect people and increase their performance by cleansing them from such negativities. Ngah Jusoff and Rahman (2009) argue that job satisfaction can be proxy for the welfare of the employee in the workplace, and that job satisfaction is positively related to El. Andrew (2011) also states that the person with high El is happier in the workplace and their performance may be higher in this context. According to Yusoff, Khan and Azam (2013), academicians will increase their performance when they work in a business environment where they can manage their emotional competencies and cooperate with other academicians and the administrative department. Thus third hypotheses related with $\mathrm{El}$ and its sub-dimensions are:

$\mathrm{H}_{3}$ : El has a moderator role in the relationship between WPH and PAP.
$\mathrm{H}_{31}$ : Self-emotional appraisal has a moderator role in the relationship between WPH and PAP.

$\mathrm{H}_{32}$ : Others' emotional appraisal has a moderator role in the relationship between WPH and PAP.

$\mathrm{H}_{33}$ : Regulation of emotions has a moderator role in the relationship between WPH and PAP.

$\mathrm{H}_{34}$ : Use of emotions has a moderator role in the relationship between WPH and PAP.

\section{WPH, WLB and PAP}

Analyzing the role of WLB as mediator role in the relationship of WPH and PAP has two phases. The first phase embodies the relationship between WPH and WLB. In this context, Korkmaz and Erdoğan (2014) found a negative relationship between job satisfaction, which is the narrower scope of WPH and WLB. That means the more satisfied employees are, the more time they can spare time for work resulting in disruption of WLB. On the other hand, Talukder, Vickers and Khan (2017) found that happy employees are more successful at maintaining WLB. Thus it is uncertain that how WPH affects WLB in the literature. In the second phase related to WLB and PAP relation, Achour, Grine and Nor (2014) made analyses with 43-45 aged female academicians. Results show that participants who suffer from work-life conflict have decreased performance. Similarly, Genç, Genç and Gümüş (2016) emphasized that performance levels of employees who cannot achieve WLB are expected to be lower. In contrast, the results of Soomro, Breitenecker and Shah' study (2017) conducted with young academicians prevails that participants who cannot maintain WLB and experience work-life conflict have higher performance. Comparing these studies, the major difference, as Soomro et al. (2017) also stated that, arises from the age. They stated that especially young employees who are at the beginning of their careers can work longer hours, thinking that they will reach their goals faster when they spend more time in the workplace. Similarly, in Fonthinha's study with British academicians (2019), there is a U-shaped relation between WLB and performance. Academicians who work up to 10 hours weekly additionally get satisfied and perform better than who work within office hours only and who work for over 10 hours additionally. According to some researches (Machlowitz, 1978 and Peiperl and Jones, 2001; cited by İlik, 2019), being workaholic, which affects WLB negatively, contributes to performance as it affects employees' satisfaction level and creativity. Thus fourth hypotheses related with WLB and its sub-dimensions are: 
$\mathrm{H}_{4}$ : There is a partial mediator role of WLB in the relationship between WPH and PAP.

$\mathrm{H}_{41}$ : There is a partial mediator role of neglecting life in the relationship between WPH and PAP.

$\mathrm{H}_{42}$ : There is a partial mediator role of work-life fit in the relationship between WPH and PAP.
$\mathrm{H}_{43}$ : There is a partial mediator role of life's comprising work in the relationship between WPH and PAP.

$\mathrm{H}_{4}$ : There is a partial mediator role of devoting time to oneself in the relationship between WPH and PAP.

In the light of this information, the research model of the study is:

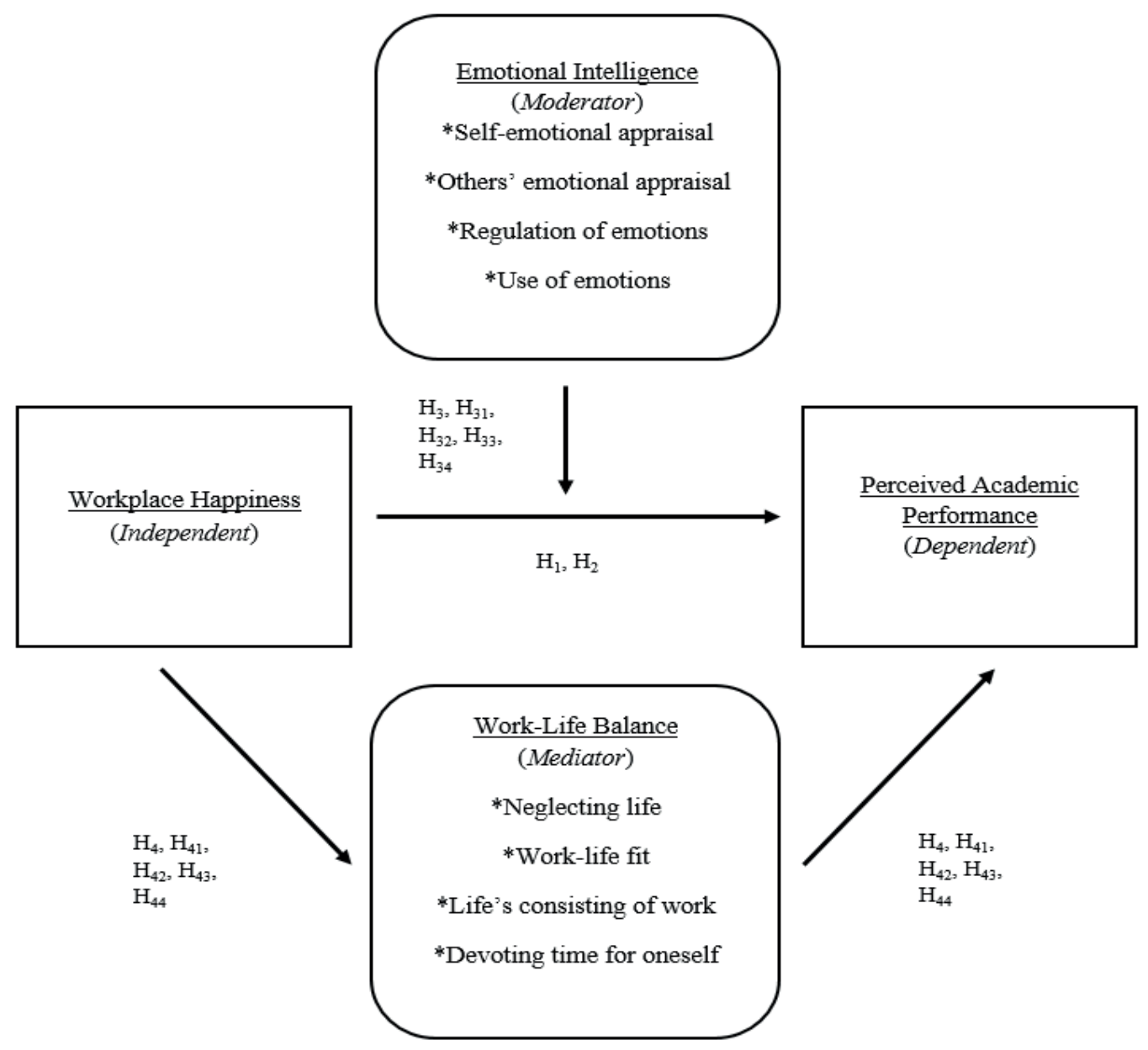

Figure 1: Research Model

\section{Method}

\section{Sample}

Academicians who work in faculties of private and public universities in Central Anatolia Region of Turkey composed the target population of the study. The reason for choosing academicians as a sample arises from the nature of their work. Because of their profession, academicians do not have a single workplace or specific hours to perform. Thus "happy employee=productive employee" stands as a question in this regard. The reason for choosing this region underlies the fact that it had the highest score of Turkey in the academic context in 2016 (Göksu and Bolat, 2017: 445) which was the first year of the implementation of academic incentive program that was put forward by government to motivate academicians. There are 42 universities in the aforementioned region. We excluded medical and dentistry faculties due to work density. By excluding them, in these universities there are 4167 professors, 2652 associate professors, 5708 assistant professors, 3434 lecturers and 6270 research assistants; 22231 working at total (HEl, 2019). Because of some technical problems such as non-existence of mail addresses or 
web pages, we sent surveys online to approximately 15000 academicians at all. We used proportional sampling technique, and the sample comprised 1184 academicians. As we detected 48 participants as outliers, we extracted them from the study and we continued the research with 1136 people. $54.9 \%$ of the sample is female $(n=624)$, while $45.1 \%$ is male $(n=512)$; mostly aged $26-40$ as $59.6 \%(n=677)$, married as $66.3 \%(n=753)$ and works as a research assistant with $39 \%(n=443)$ followed by assistant professors $(n=263)$. Majority work for a public university as $84.6 \%(n=961)$ and working time is mostly 6-15 years $(n=438)$.

\section{Measurements}

All the scales used in this study were chosen either because they were developed for academicians or because they gave ideal results when implemented on aforementioned participants. PAP, El, and WLB scales were developed in Turkey for academicians, thus may not make any cultural differences, and the WPH scale was developed by a global institution and it was handled within academicians during the adaptation phase to Turkish. Besides, for obtaining normality of distribution, we conducted a seven-point Likert scale.

\section{WPH}

Psychiatric Researches Unit, WHO Collaborating Center for Mental Health, Frederiksborg General Hospital developed WPH scale in 1998. The scale is composed of 5 items which involves 4 positive items such as "I feel cheerful at work" and a negative item as "I feel nervous at work" in one factor. The scale was adapted into academic workplace context and translated into Turkish by Alparslan (2016).

\section{PAP}

Scale, which was developed by Gür (2017), has five components such as effective lecturing, self-efficacy of foreign language, scientific research, technology and environmental factors that analyze the perception of academic performance. Scale is composed of 19 positive items such as"I can do data analysis of my research without help" and 7 negative items as "When faced with difficulties, I stop my research".

\section{EI}

We used Wong and Law's scale (2002) to measure El. This scale has been derived from Mayer and Salovey's (1997) four factor-scale. The scale is composed of 16 positive items such as "I can control my emotions well" and includes four dimensions as mentioned in hypotheses development. The scale was translated into Turkish and used for academicians by llgın (2010) with serial approach method.

\section{WLB}

The scale used in this study was developed to measure academicians' levels of WLB. It was developed by Apaydın (2011) and composed of four dimensions as mentioned in hypotheses development. There are 12 positive items such as "I think I have allocated my time appropriately both in my business and private life" and 18 negative items as "I cannot keep up with the intensity of my work".

\section{Procedure}

Before starting, ethical approval form was obtained from Kırıkkale University Ethical Approval Committee. We preferred online-survey method in order to reach more people and due to time and cost constraints. The survey form was prepared and sent online to mail addresses of academicians, which they stated on their institutional pages. The form comprised demographic questions besides scales. In the beginning of the form, there was an informed consent. We replied to each participant who experienced difficulties in understanding the items. Most participants gave feedback about the survey and the items. Thus it took nearly four months to collect data.

All data are collected by self-report for some reasons. First, happiness is a subjective judgment and no one can claim about another one's happiness level (Januwarsono, 2015), so it requires self-report evaluation. Second, we measured the perceived performance instead of what objective criteria reveal. Because academic performance is relatively more difficult than other job performances due to universities' organizational structures (Ünal, 2017) and the uncertainty as to which of the academic performance components is more important, or whether they should be considered as equally important. Third, we wanted to see how balanced the academicians feel their work and private lives. Last, we thought that in such a competitive work-setting like academia, it would be more objective evaluation of El levels of participants in terms of self-reports. Another reason is that the time and money constraints that prevented us from doing such professional El tests. 


\section{Reliability and Validity of Scales}

The scales' reliabilities are found as Cronbach's $\alpha=$ $.849, .897, .904$ and .896 for WPH, PAP, El and WLB respectively, which are considerably high. For validation of the scales, first EFA was conducted. WPH was explained with five items in one factor which adheres to its original form with a variance of $64.173 \%$ and $\mathrm{KMO}$ value as 849. PAP was explained with four factors including 10, five, three and two items respectively with a variance of $57.511 \%$ at total. Three items ( $2 \mathrm{nd}, 10$ th and $26 \mathrm{th}$ ) were extracted from the scale due to overlapping. Apart from this, the remaining items were united in factors as its original form except for the items of self-efficacy of technology and effective lecturing originally. They were re-checked and gathered in one factor called as effective lecturing and self-efficacy of technology because of their common coverages. KMO value was found as .905. El scale was explained with four factors involving four items per each concretely based on the original form with a variance of $77.168 \%$ and $\mathrm{KMO}$ value was .883 . WLB was explained with four factors including eight, five, five, and three items respectively with a variance of $55.561 \%$ at total. Six items (2nd, 14th, 16th, 18th, 20th and 21st) which were excluded from the original scale too, were extracted due to overlapping. Three more items (4th, 15thi and 26th) were extracted due to the same reason. Because remaining items united in each factor adhere to original form, they were renamed same. KMO value was found as .910. After then for psychometric validity of each scale, CFA was conducted. The fit indices are $x^{2}=7.76, \mathrm{df}=4, \mathrm{CFI}=.999, \mathrm{GFI}=.997$, $\mathrm{TLI}=.997, \mathrm{RMSEA}=.029$ for WPH after one modification; $\mathrm{X}^{2}=739.232, \mathrm{df}=152, \mathrm{CFI}=.946, \mathrm{GFI}=.937, \mathrm{TLI}=.932, \mathrm{RM}-$ $\mathrm{SEA}=.058$ for PAP after six modifications, $\mathrm{x}^{2}=474.137$, $\mathrm{df}=97, \mathrm{CFl}=.972, \mathrm{GFI}=.950, \mathrm{TLI}=.966, \mathrm{RMSEA}=.059$ for El after one modification and $x^{2}=876,392, d f=180$, $\mathrm{CFI}=.952, \mathrm{GFI}=.929, \mathrm{TLI}=.909$, RMSEA $=.059$ for WLB after three modifications.

\section{Results}

In this study, data were analyzed via SPSS 21.0. For determining the moderating and mediating effects of $\mathrm{EI}$ and WLB respectively, we conducted hierarchical regression by Process Macro for SPSS V3.4 developed by Andrew F. Hayes, 2018 rather than SEM. This is because we wanted to see the direct effect of WPH on PAP exclusively. SEM would be more appropriate in order to make comparisons of direct and indirect effects of independent variable on a dependent one (Stock, 2016).

Table 1: Correlation Table of Variables

\begin{tabular}{|c|c|c|c|c|c|c|c|c|c|c|c|c|}
\hline & $M$ & s.d. & 1 & 2 & 3 & 4 & 5 & 6 & 7 & 8 & 9 & 10 \\
\hline 1.Gender & 1.45 & .50 & 1 & & & & & & & & & \\
\hline 2.Age & 247 & .72 & $.19^{* *}$ & 1 & & & & & & & & \\
\hline 3.Marital Status & 1.34 & .47 & $-.18^{* *}$ & $-.25^{* *}$ & 1 & & & & & & & \\
\hline 4.Title & 3.61 & 1.53 & $.21^{* *}$ & $.72^{* *}$ & $-.30^{* *}$ & 1 & & & & & & \\
\hline 5.Working Time & 2.35 & 1.15 & $.15^{* *}$ & $.83^{* *}$ & $-.30^{* *}$ & $.75^{* *}$ & 1 & & & & & \\
\hline 6.University Type & 1.17 & .44 & $.06^{*}$ & $.16^{* *}$ & $-.09 * *$ & .00 & $-.07^{*}$ & 1 & & & & \\
\hline 7.WPH & 5.13 & 1.10 & $.06^{*}$ & $.16^{* *}$ & $-.09 * *$ & $.16^{* *}$ & $.13^{* *}$ & .02 & 1 & & & \\
\hline 8.PAP & 5.18 & .79 & $.06^{*}$ & $.08^{*}$ & $-.06^{*}$ & $.19^{* *}$ & $.10^{* *}$ & $.07^{*}$ & $.24 * *$ & 1 & & \\
\hline 9.El & 5.66 & 69 & -.03 & $.24^{* *}$ & $-.10^{* *}$ & $.22^{* *}$ & $.24^{* *}$ & -.04 & $.34^{* *}$ & $.36^{* *}$ & 1 & \\
\hline 10.WLB & 4.69 & .76 & .03 & $.20^{* *}$ & $-.15^{* *}$ & $.20^{* *}$ & $.19^{* *}$ & .05 & $.39 * *$ & $.25^{* *}$ & $.35^{* *}$ & 1 \\
\hline
\end{tabular}

** Significant at the 0.01 level *Significant at the 0.05 level

From the data above, we see that there is a weak but positive relationship $(r=.241)$ between WPH and PAP which means $\mathrm{H}_{1}$ is supported.
Table 2: Hierarchical Regression Analysis-Moderator Effect of El

\begin{tabular}{llll}
\hline & Model 1 & Model 2 & Model 3 \\
\hline WPH & .173 & .105 & .118 \\
$\mathrm{El}$ & & .249 & .259 \\
$\mathrm{WPH}^{*} \mathrm{El}$ & & & .075 \\
$\mathrm{R}^{2}$ & .058 & .146 & .157 \\
$\Delta \mathrm{R}^{2}$ & .058 & .088 & .011 \\
$\mathrm{~F}$ & $70.122^{* * *}$ & $97.002^{* * *}$ & $70.276^{* * *}$ \\
$\mathrm{~N}$ & 1136 & 1136 & 1136 \\
\hline $\begin{array}{l}\text { Durbin-Watson }=1.966 \\
\text { *** } p<0.001\end{array}$ & Tolerance $=.952$ & $\mathrm{VIF}=1.050$ \\
\hline
\end{tabular}


In Model 1, it is seen that WPH explains approximately $6 \%$ of PAP's variance and affects it positively $(\beta=.173, p<0.01)$. Thus, $\mathrm{H}_{2}$ is accepted.

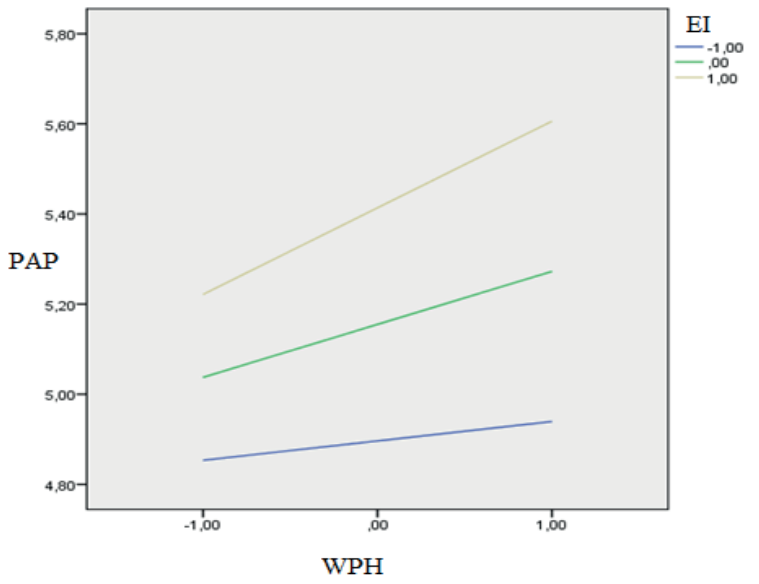

Figure 2: Moderating Effect of El

Table 2 also prevails that the effect of WPH on PAP increases with El which has a moderating role $(\beta=.157$; $p<0.01$ ) in the relationship. In Figure 2 , by taking the values of one standard deviation (s.d) below and above the means of El, it was proved that the effect of WPH on PAP increases when the El level of academicians is high. Thus, $\mathrm{H}_{3}$ is also accepted.

Table 3: Hierarchical Regression Analysis-Moderator Effect of Self-Emotional Appraisal

\begin{tabular}{llll}
\hline & Model 1 & Model 2 & Model 3 \\
\hline WPH & .173 & .157 & .162 \\
$\begin{array}{l}\text { Self-Emotional } \\
\text { Appraisal (EISD1) }\end{array}$ & & .143 & -.101 \\
WPH*EISD1 $^{2}$ & & .055 \\
$\mathrm{R}^{2}$ & .058 & .089 & .096 \\
$\Delta \mathrm{R}^{2}$ & .058 & .031 & .007 \\
$\mathrm{~F}$ & $70.122^{* * *}$ & $55.514^{* * *}$ & $39.947^{* * *}$ \\
$\mathrm{~N}$ & 1136 & 1136 & 1136 \\
\hline $\begin{array}{l}\text { Durbin-Watson }=1.959 \\
* * *\end{array}<0.001$ & Tolerance $=.948$ & VIF $=1.055$ \\
\hline
\end{tabular}

The effect of WPH on PAP increases with self-emotional appraisal $(\beta=.096 ; p<0.01)$ which is the first sub-dimension of El, as presented in Table 3. In Figure 3, by taking the values of $\mathrm{s}$.d. below and above the means of this dimension, it was proved that the effect of WPH on PAP increases when academicians appraise their own emotions, which leads to $\mathrm{H}_{31}$ acceptance.

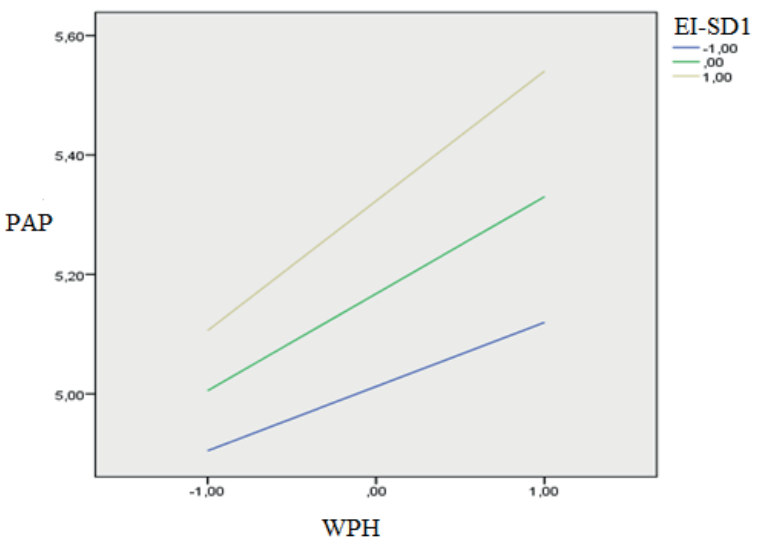

Figure 3: Moderating Effect of Self-Emotional Appraisal

Table 4: Hierarchical Regression Analysis-Moderator Effect of Others' Emotional Appraisal

\begin{tabular}{llll}
\hline & Model 1 & Model 2 & Model 3 \\
\hline WPH & .173 & .179 & .179 \\
$\begin{array}{l}\text { Others'Emotional } \\
\text { Appraisal (EISD2) }\end{array}$ & & .023 & .111 \\
$\mathrm{WPH}^{*}$ EISD2 & & & .036 \\
$\mathrm{R}^{2}$ & .058 & .077 & .080 \\
$\Delta \mathrm{R}^{2}$ & .058 & .019 & .003 \\
$\mathrm{~F}$ & $70.122^{* * *}$ & $47.275^{* * *}$ & $32.620^{* * *}$ \\
$\mathrm{~N}$ & 1136 & 1136 & 1136 \\
\hline $\begin{array}{l}\text { Durbin-Watson }=1.969 \\
* * *\end{array}<0.001$ & \multicolumn{2}{l}{ Tolerance $=.998$} & VIF $=1.002$ \\
\hline
\end{tabular}

Because interaction term (WPH*EISD2) is not significant in the model ( $p>0.05)$, we cannot prove that this sub-dimension has a moderating effect in the relation. Thus $\mathrm{H}_{32}$ is rejected.

Table 5: Hierarchical Regression Analysis-Moderator Effect of Use of Emotions

\begin{tabular}{llll}
\hline & Model 1 & Model 2 & Model 3 \\
\hline WPH & .173 & .087 & .093 \\
Use of Emotions (EISD3) & & .312 & .033 \\
WPH*EISD3 & & & .06 \\
$\mathrm{R}^{2}$ & .058 & .198 & .204 \\
$\Delta \mathrm{R}^{2}$ & .058 & .140 & .006 \\
$\mathrm{~F}$ & $70.122^{* * *}$ & $139.552^{* * *}$ & $96.829^{* * *}$ \\
$\mathrm{~N}$ & 1136 & 1136 & 1136 \\
\hline $\begin{array}{l}\text { Durbin-Watson }=1.997 \\
* * * p<0.001\end{array}$ & \multicolumn{4}{l}{ Tolerance $=.938$} & VIF $=1.066$ \\
\hline
\end{tabular}


Table 5 shows that the effect of WPH on PAP increases with use of emotions $(\beta=.06 ; p<0.01)$ which is the third sub-dimension of El. In Figure 4, by taking the values of s.d. below and above the means of this dimension, it was proved that the effect of WPH on PAP increases when academicians use their emotions, which leads to $\mathrm{H}_{33}$ acceptance.

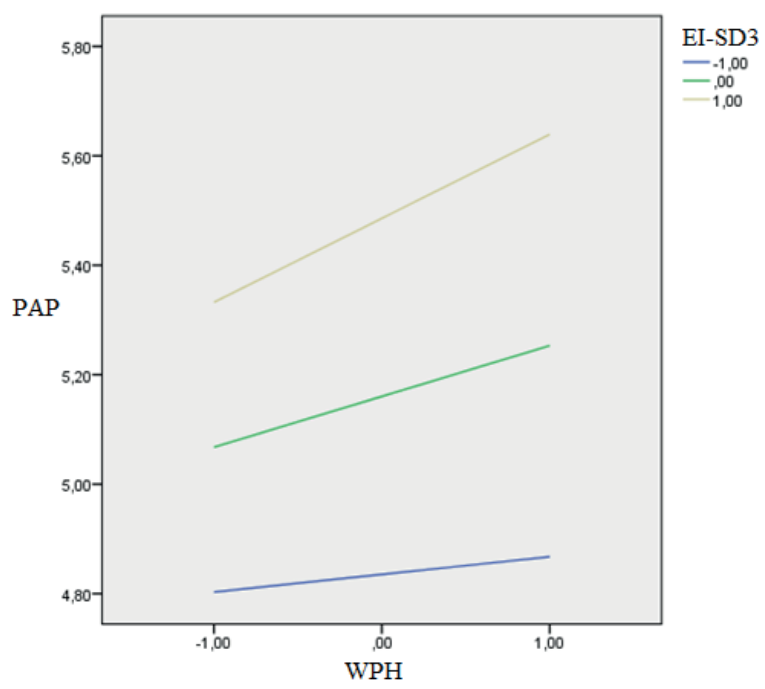

Figure 4: Moderating Effect of Use of Emotions

Table 6: Hierarchical Regression Analysis-Moderator Effect of Regulation of Emotions

\begin{tabular}{|c|c|c|c|}
\hline & Model 1 & Model 2 & Model 3 \\
\hline WPH & .173 & .148 & .162 \\
\hline $\begin{array}{l}\text { Regulation of } \\
\text { Emotions (EISD4) }\end{array}$ & & .140 & .162 \\
\hline WPH*EISD4 & & & .083 \\
\hline$R^{2}$ & .058 & .087 & .102 \\
\hline$\Delta \mathrm{R}^{2}$ & .058 & .029 & .005 \\
\hline $\mathrm{F}$ & $70.122^{* * *}$ & $53.887^{* * *}$ & $43.062^{* * *}$ \\
\hline $\mathrm{N}$ & 1136 & 1136 & 1136 \\
\hline $\begin{array}{l}\text { Durbin-Watson }=1.983 \\
* * * p<0.001\end{array}$ & 3 Toleran & $e=.916$ & $V I F=1.092$ \\
\hline
\end{tabular}

Table 6 reveals that the effect of WPH on PAP increases with regulation of emotions $(\beta=.102 ; p<0.01)$ which is the fourth sub-dimension of El. In Figure 6 , by taking the values of s.d. below and above the means of this dimension, it was proved that the effect of WPH on PAP increases when academicians regulate their emotions. Hence, $\mathrm{H}_{34}$ is accepted.

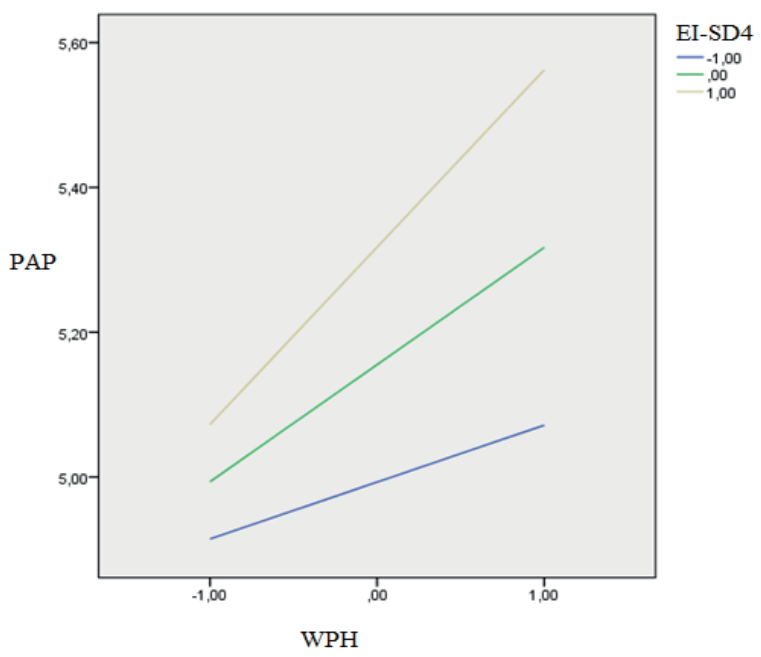

Figure 5: Moderating Effect of Regulation of Emotions

In the last phase, we investigated the mediating effect of WLB and its sub-dimensions in the relationship according to Baron and Kenny steps (1986). 
Table 7: Mediator Effects of WLB and Its Sub-Dimensions

\begin{tabular}{|c|c|c|c|}
\hline & Model 1 (DV: WLB) & Model 2 (DV: PAP) & Model 3 (DV:PAP) \\
\hline WPH & .272 & .173 & .123 \\
\hline WLB & & & .183 \\
\hline $\mathrm{R}^{2}$ & .153 & .058 & .085 \\
\hline$\Delta \mathrm{R}^{2}$ & & & .033 \\
\hline$F$ & $204.252^{* * *}$ & $70.1218^{* * *}$ & $55.535^{* * *}$ \\
\hline \multirow{3}{*}{ Durbin - Watson $=1.950$} & 1136 & 1136 & 1136 \\
\hline & Tolerance $=.847$ & $V I F=1.180 \quad * * * p<0.001$ & Sobel $p$ value $>0.05$ \\
\hline & odel 1 (DV: WLBSD1) & Model 2 (DV: PAP) & Model 3 (DV:PAP) \\
\hline WPH & .024 & .173 & 115 \\
\hline Neglecting Life & & & .172 \\
\hline$R^{2}$ & .148 & .058 & .096 \\
\hline$\Delta \mathrm{R}^{2}$ & & & 0.038 \\
\hline$F$ & $196.800^{* * *}$ & $70.1218^{* * *}$ & $60.325^{* * *}$ \\
\hline $\mathrm{N}$ & 1136 & 1136 & 1136 \\
\hline \multirow[t]{2}{*}{ Durbin- Watson $=1.934$} & Tolerance $=.852$ & $V I F=1.174{ }^{* * *} p<0.001$ & Sobel $p$ value $<0.05$ \\
\hline & Model 1 (DV: WLBSD2) & Model 2 (DV: PAP) & Model 3 (DV:PAP) \\
\hline WPH & .174 & 173 & 162 \\
\hline Work-Life Fit & & & .064 \\
\hline$R^{2}$ & .0534 & .058 & .063 \\
\hline$\Delta \mathrm{R}^{2}$ & & & .005 \\
\hline$F$ & $64.003^{* * *}$ & $70.1218^{* * *}$ & $37.8035^{* * *}$ \\
\hline $\mathrm{N}$ & 1136 & 1136 & 1136 \\
\hline \multirow[t]{2}{*}{ Durbin-Watson $=1.972$} & Tolerance $=.947$ & $V I F=1.056{ }^{* * *} p<0.001$ & Sobel $p$ value $<0.05$ \\
\hline & Model 1 (DV: WLBSD3) & Model 2 (DV: PAP) & Model 3 (DV:PAP) \\
\hline WPH & .439 & .173 & .078 \\
\hline Life's Consisting of Work & & & 217 \\
\hline$R^{2}$ & .187 & .058 & .135 \\
\hline$\Delta \mathrm{R}^{2}$ & & & .077 \\
\hline$F$ & $261.295^{* * *}$ & $70.1218^{* * *}$ & $88.0034^{* * *}$ \\
\hline $\mathrm{N}$ & 1136 & 1136 & 1136 \\
\hline \multirow[t]{2}{*}{ Durbin- Watson $=1.960$} & Tolerance $=.813$ & $V I F=1.23 \quad * * * x<0.001$ & Sobel $p$ value $<0.05$ \\
\hline & Model 1 (DV: WLBSD4) & Model 2 (DV: PAP) & Model 3 (DV:PAP) \\
\hline WPH & .174 & .173 & .162 \\
\hline Devoting Time to Oneself & & & .064 \\
\hline$R^{2}$ & .0534 & .058 & .063 \\
\hline$\Delta \mathrm{R}^{2}$ & & & .005 \\
\hline$F$ & $64.003^{* * *}$ & $70.1218^{* * *}$ & $37.8035^{* * *}$ \\
\hline \multirow[b]{2}{*}{ Durbin-Watson = } & 1136 & 1136 & 1136 \\
\hline & Toleran & $V I F=1.012$ & $p<0.001$ \\
\hline
\end{tabular}

In Table 7, neglecting life, life's comprising work and work-life fit sub-dimensions are providing partially mediator roles in the relationship. WPH positively affects neglecting life $(\beta=.174 ; p<0.01)$ and neglecting life positively affects PAP $(\beta=.172 ; p<0.01)$. When neglecting life was introduced to model, the effect of
WPH on PAP decreases $(b 1=.173=>b 2=.123)$, but not becomes insignificant. Similarly, WPH positively affects life's comprising work positively $(\beta=.439 ; p<0.01)$ which affects PAP in the same direction $(\beta=.217 ; p<0.01)$. When this dimension was introduced to model, the effect of WPH on PAP decreases ( $b 1=.173=>b 2=.078$ ), 
but not becomes insignificant. Last, WPH positively affects work-life fit $(\beta=.174 ; p<0.01)$ which affects PAP in the same way $(\beta=.064 ; p<0.01)$. When it was added to model, the effect of WPH on PAP decreases (b1 $=.173=>b 2=.162$ ), but not becomes insignificant. Sobel Tests proved these sub-dimensions' mediating roles as significant $(\mathrm{p}<0.01)$. Thus, $\mathrm{H}_{41}, \mathrm{H}_{42}$ and $\mathrm{H}_{43}$ were supported. Despite all criteria for mediating effect has been met, since Sobel Test did not approve ( $p>0.05$ ), WLB was not found as mediator. Thus $\mathrm{H}_{4}$ was rejected. Last, because of insignificance of devoting time to oneself sub-dimension in the model ( $p>0.05)$, it was not found as mediator either. For this reason, $\mathrm{H}_{44}$ was also rejected.

\section{Conclusion and Discussion}

This study fills the gap in the literature by validating the thesis of "happy employee=productive employee" in an academic setting. Despite of positive relationship and effect, the power of both correlation $(r=.241)$ and regression $\left(R^{2}=.058\right)$ were found relatively low. There are probable reasons for this result. First, AP is measured in a perceptional context. Because all scales were made by self-assessment in order to ensure the consistency of the study results. Instead, if objective criteria were preferred, it would be likely that there will be changes in the explanatory effect of WPH on PAP. Second and maybe the most important, academicians do not perform only at workplace or during office hours. They keep working at least mentally by sparing time in their private lives, especially for academic publications. Thus, it is so rational that the effect of a positive emotional situation at their workplace on their performance may be that low. Moreover, they are mostly busy with administrative tasks, which lowers the impact of WPH on performance, even affects negatively, when they are at work. Third, there are many individual, organizational and job-related factors that explain AP's variance. In this context, $6 \%$ explaining power of WPH among those many factors may be counted as expected.

Second goal was to analyze the El and its sub-dimensions in moderating role in the thesis. Results showed El has moderated the relationship. The situation that WPH's effect on PAP is at the highest point when El is highest, is consistent with the literature (Ngah et al., 2009; Andrew, 2011; Balanescu, 2018). Moreover three of its sub-dimensions also played the moderating role. Happy academicians at work show performance at maximum level when they can appraise, use and regulate their own emotions. The only sub-dimension found statistically insignificant is appraising of others' emotion. Considering all sub-dimensions, significant ones are related with self, but the insignificant one is related with other. This situation proves that in a relationship between WPH, which is a subjective term and PAP that is also subjective assessment, factors to play moderator roles would be expected as self-assessed El and its self-related sub-dimensions.

The third goal was to analyze WLB and its sub-dimensions in partially mediating role in this thesis in reverse logic. The rationale here is when academicians feels happy at workplace, their PAP will rise because they will spend more time at work. Focal point of PAP means, the more time spent at work might not lead to higher performance but at least a rise in perception of it. Fontinha et al.'s study (2019) also supported this claim. The result of their study with British academicians' show that up to additional 10 hours to weekly office hours makes them feel more satisfied, controlled over their jobs and highly performed. Second point is the disruption of WLB should happen at workplace, which can be called as work-life conflict. In Soomro et al.'s study with Pakistani academicians (2017), it is obtained that work-family conflict affects performance positively with the idea that academicians feel like they outperform than usual when they spend more time at office. Thus, just like in Border theory (Clark, 2000), workplace has its own borders to work and an academician should spend his working time at this place, not in his private life by sparing time of it for work. In the study, though WPH affected WLB positively and did WLB so PAP, WLB did not mediate the relationship. But its two sub-dimensions served for our aforementioned claim. Results showed WPH affected neglecting life and life's comprising work sub-dimensions positively and they affected PAP in the same way, and they also mediated the relationship. Apart from this, work-life fit also partially mediated this relationship in opposition to this claim, but complying with the literature. Difference arises from two opponent views of model mentioned in WLB part. Fourth sub-dimension, devoting time to oneself, did not mediate the relationship. The reason underlies the fact that disruption of WLB does not happen at workplace, which can be explained by Clark's Border theory in which natural areas where one can spare time for himself are considered as areas outside of the workplace. It is a rational situation that the sub-dimension of devoting time to himself does not undertake the mediating role in the effect of WPH on PAP, if the environment in which the person should spare time for himself or his family is not a workplace. 
All the variables in the study gained scores above average. El and PAP were expected to be rather high because of subjective judgements. This is due to Personal Identity theory which claims that people strive for positive self-definitions (Dutton et al., 2010). While the score of WPH is most welcome, WLB comes as a surprise in contrary to the literature (Fontinha et al., 2019). It can be explained by Miller's (2008) sense of imbalance thesis which claims that if a job is not perceived as meaningful by the person performing the job, the feeling of imbalance may prevail. Scholarship includes duties such as benefiting society at the most basic level, producing and sharing information and engaging in managerial activities makes the profession meaningful. Apart from this, flexibility and autonomy provided for them may also lead to this result.

With this study, we made contributions to literature. First, we filled the gap by validating the thesis of "happy employee $=$ productive employee" in an academic setting by showing that performance of an occupation whose employees' productivity is not limited to office hours and workplace borders can be improved by WPH directly. This direct relationship can be strengthened via employees' El levels. On the other hand, the relationship can be partially mediated indirectly with WLB. We proved WLB can affect performance positively when it is not ensured.

\section{Limitations and Suggestions}

This study has some limitations inevitably. First, the data were obtained from the same type of source which could lead to common-method bias or variance. To reduce this risk, as aforementioned, we responded participants to assure their confidentiality. Because the participants are academicians, we expected from them filling the questions not for social desirability, instead in reality. Regarding the bias, this study is cross-sectional. Literature suggests that in mediation analyses, longitudinal studies are more appropriate (Maxwell and Cole, 2007), unless the authors present a reason for the temporal order of factors (Fairchild and McDaniel, 2017). Furthermore, in a study where cross-sectional and longitudinal mediation results are compared, if the purpose is to draw conclusions processes which unfold over time, the authors discourages that using the mediation analysis with cross-sectional data (O'Laughlin, Martin and Ferrer, 2018). In this research, we collected the data of all variables at the same time, instead of a longitudinal process. The rationale here is that the perception part of academic performance is short term and simultaneously happening as well as happiness and the perception of WLB in temporal and involvement contexts. Happy academicians would think they are more productive because they are spending more time at workplace at that time. Moreover, we do not claim that happiness increases academic performance in general, just the perception of it. Its effect on AP is another issue. Besides, the data used in this research is proper to meet the mediation requirements discussed by Baron and Kenny (1986). Second, we used PAP scale. Objective criteria may be used to assess the AP and make comparisons. Third, we used general WPH scale. Instead, by considering the nature of academia, a specific scale could be developed and test the hypotheses again. Fourth, this study was conducted in Turkey. An international study with different research cultures can be applied to make comparisons. Fifth, medicine and dentistry faculties were omitted because of their dense workloads. Analyzes in these two types of faculties, which are in constant communication and interaction with different people in the workplace, may yield different results.

Considering the status of AP in Turkey, to improve it, academicians in administrative positions should provide an environment with happiness, qualified social relations, regarding scientific knowledge and autonomy. Superior ones should motivate and guide the beginners. In this study, we found that the more happiness and the more time spent at workplace result in higher performance perception. Nevertheless, this study was conducted in north semi-sphere like Fontinha et al.'s study (2019), which managers in south should take into consideration. The study also shows that the effect of WPH on PAP gets stronger with El, which can be improved with education. Thus, training seminars may be provided for beginners. 


\section{References}

Achour, Meguellati, Grine, Fadila, \& Nor, Mohd R. M. N. (2014). Work-family conflict and coping strategies: qualitative study of Muslim female academicians in Malaysia. Mental Health, Religion \& Culture, 17 (10), 1002-1014. https://doi.or $\mathrm{g} / 10.1080 / 13674676.2014 .994201$.

Ak, Mehmet, \& Gülmez, Ahmet (2006). Türkiye'nin uluslararası yayın performansının analizi. Akademik Incelemeler Dergisi, 1(1), 22-49.

Alici, İsmail, \& Yılmaz, Hüseyin (2017). Duygusal zeka ve alt boyutlarının ilişki yönetimi üzerine etkisi: ampirik bir uygulama. Örgütsel Davranış Araştırmaları Dergisi, 2 (1), 70-89. ISSN: 2528-9705.

Alparslan, Ali, M., Kahraman, Mehmet, \& Cantürk, Nihal (2016, May). Araştırma Görevlilerinin İşyerinde Mutluluk ve Mutsuzluk Nedenleri: Bir Alan Araştırması. 15. Ulusal İşletmecilik Kongresi, İstanbul Üniversitesi, İstanbul.

Andrew, Sharon, S., (2011). S.M.I.L.E.S.: The differentiating quotient for happiness at work. Social Sciences and Medicine, 1-13.

Apaydın, Çiğdem (2011). Öğretim üyelerinin işe bağımlılık düzeyi ile iş-yaşam dengesi ve iş-aile yaşam dengesi arasındaki ilişki. Doctoral Dissertation, Ankara University, Eğitim Bilimleri Enstitüsü.

Ardıç, Kadir, \& Erbaşaran, Zeynel (2019). İşkoliklik ve iş tatmini arasındaki ilişkinin incelenmesi. Avrasya Sosyal ve Ekonomi Araştırmaları Dergisi, 6 (4), 334-346. ISSN: 2148-9963.

Argon, Türkan (2010). A qualitative study of academicians' views on performance evaluation, motivation and organizational justice. International Online Journal of Educational Sciences, 2(1), 133-180. ISSN: 1309-2707.

Aytekin, İhsan, Erdil, Oya, Erdoğmuş, Nihat, \& Akgün, Ali, E. (2016). Academicians' career capital and career satisfaction: the mediation effect of research productivity, Kuram ve Uygulamada Eğitim Bilimleri, 16(6), 1921-1945. DOI: 10.12738/ estp.2016.6.0412.

Baba, Mubashir, M. (2017). Emotional intelligence, organizational commitment, and job satisfaction: a study of higher learning institutions. Amity Global Business Review, 51-60. DOI: 10.1016/j.sbspro.2011.11.447.

Bakker, Arnold, B., Oerlemans, Wido, G., M. (2010). In Spreitzer, G. M., \& Cameron, K. S. (Eds.), Subjective well-being in organizations. Handbook of positive organizational scholarship (pp. 1-31), Oxford University Press. DOI: 10.1093/ oxfordhb/9780199734610.013.0014.

Balanescu, Ramona, C. (2018, April). Emotional intelligence - a possible predictor of performance or success at organizational and individual level?!. The 14th International Scientific Conference eLearning and Software for Education, Bucharest. ISSN: 2066-8821.

Baron, Reuben, M., \& Kenny, David, A. (1986). The moderator-mediator variable distinction in social psychological research: conceptual, strategic and statistical considerations. Journal of Personality and Social Psychology, 51 (6), 1173-1182. DOI: 10.1037//0022-3514.51.6.1173.
Bibliometric Analyses - SCOPUS (2019). Retrieved from cabim. ulakbim.gov.tr/bibliyometrik-analiz/scopus-turkiye-adresli-veriler/. Accessed February 8, 2021.

Bibliometric Analyses - WoS (2019). Retrieved from cabim. ulakbim.gov.tr/bibliyometrik-analiz/wos-turkiye-adresli-veriler/. Accessed February 8, 2021.

Boehm, Julia, K., \& Lyubomirsky, Sonja (2008). Does happiness promote career success?. Journal of Career Assessment, 16 (1), 101-116. https://doi.org/10.1177/1069072707308140.

Bozkurt, Öznur \& Ercan, Armağan (2017). Akademik iyimserlik ile performans arasındaki ilişkinin akademisyenler açısından değerlendirilmesi. Uluslararası Yönetim Iktisat ve Işletme Dergisi, ICMEB17 Special Issue, 251-254.

Clark, Sue, C. (2000). Work-family border theory: a new theory of work-family balance. Human Relations, 53 (6), 747-770. https://doi.org/10.1177/0018726700536001.

Çöl, Güner (2008). Algılanan güçlendirmenin işgören performansı üzerine etkileri. Doğuş Üniversitesi Dergisi, 9(1), 35-46. ISSN: 1308-6979

Diener, Ed, \& Seligman, Martin E. P. (2002). Very happy people. Psychological Science, 13 (1), 81-84. https://doi. org/10.1111/1467-9280.00415.

Diener, Ed, Suh, Eunkook M., Lucas, Richard. E., \& Smith, Heidi L. (1999). Subjective well-being: three decades of progress. Psychological Bulletin, 125 (2), 276-302. DOI: 10.1037/00332909.125.2.276.

Doğrul, Burcu Ş., \& Tekeli, Seda (2010). İş-yaşam dengesinin sağlanmasında esnek çalışma. Sosyal ve Beşeri Bilimler Dergisi, 2 (2), 11-18. ISSN: 1309-8012.

Dutton, J. E., L. M. Roberts, and J. Bednar. 2010. Pathways for positive identity construction at work: Four types of positive identity and the building of social resources. Academy of Management Review 35 (2):265-93.

Ertekin, Cumhur (2014). Bilimsel araştırma ve bilimsel performans ölçümü. TJN, 20(2), 32-36. DOI: 10.4274/tnd.80269.

Fairchild, Amanda J., McDaniel, Heather L. (2017). Best (but oft-forgotten) practices: mediation analysis. Am J Clin Nutr., 105(6), 1259-1271. DOI: 10.3945/ajcn.117.152546.

Fisher, Cynthia D. (2010). Happiness at work. International Journal of Management Reviews, 12, 384-412. DOI: 10.1111/j.1468-2370.2009.00270.x.

Fontinha, Rita, Easton, Simon, \& Laar, Darren, V. (2019). Overtime and quality of working life in academics and non-academics: the role of perceived work-life balance. International Journal of Stress Management, 26 (2), 173-183. DOI: $10.1037 /$ str0000067.

Foy, Tommy, Dwyer, Rocky J., Nafarrete, Roy, Hammoud, Mohammad S. S., \& Rockett, Pat (2019). Managing job performance, social support and work-life conflict to reduce workplace stress. International Journal of Productivity and Performance Management, 68 (6), 1018-1041. https://doi.org/10.1108/IJPPM-03-2017-0061. 
Genç, Seray, G., Genç, Volkan, Gümüş, Murat (2016). Otel işletmelerinde duygusal zekanın iş stresi ve iş yaşam dengesi üzerindeki etkisi. Batman Üniversitesi Yaşam Bilimleri Dergisi, $6(2 / 1), 97-112$.

Ghabban, Fahad, Selamat, Ali, \& Ibrahim, Roliana (2018). New model for encouraging academic staff in Saudi universities to use IT for knowledge sharing to improve scholarly publication performance. Technology in Society, 55, 92-99. https://doi.org/10.1016/j.techsoc.2018.07.001.

Goleman, Daniel (2007). İşbaşında Duygusal Zeka. Handan Balkara, (Eds.) Varlık Publications, İstanbul.

Göksu, İdris \& Bolat, Yusuf İ. (2017). Akademik teşvik uygulamasının ilk sonuçlarına ait değerlendirmeler. Yükseköğretim ve Bilim Dergisi, 7(3), 441-452. DOI: 10.5961/ jhes.2017.221.

Greenhaus, Jeffrey H., Collins, Karen M., \& Shaw, Jason D. (2003). The relation between work-family balance and quality of life. Journal of Vocational Behavior, 63, 510-531. https://doi. org/10.1016/S0001-8791(02)00042-8.

Guest, David E. (2002). Perspectives on the study of work-life balance. Social Sciences Information, 41 (2), 255-279. DOI: 10.1177/0539018402041002005.

Gür, Recep. (2017). Development of the academic performance perception scale. Eurasian Journal of Educational Research, 69, 177-197. DOI: http://dx.doi.org/10.14689/ ejer.2017.69.10.

Houston, Don, Meyer, Luanna, H., \& Paewai, Shelley. (2006). Academic staff workloads and job satisfaction: expectations and values in academe. Journal of Higher Education and Policy Management, 28(1), 17-30. https://doi. org/10.1080/13600800500283734.

Ilgın, Burcu (2010). Örgütsel vatandaşlık davranışlarının oluşumunda ve sosyal kaytarma ile ilişkisinde, duygusal zeka ve lider üye etkileşiminin rolü, Doctoral Dissertation, Hacettepe University, Ankara, Turkey.

İnce, Mehmet, Gül, Hasan, \& Gözükara, M. Yavuz (2015). Duygusal zeka ile işgören performansı arasındaki ilişkiler üzerine ampirik bir araştırma. Gümüşhane Üniversitesi Sosyal Bilimler Elektronik Dergisi, 12, 226-245.

Iplik, Esengül (2019). İşkolikliğin çalışan tutum ve davranışları üzerine etkisinde iş-yaşam dengesinin rolü. Business and Economics Research Journal, 10 (4), 929-943. doi: 10.20409/ berj.2019.211.

Januwarsono, Santoso (2015). Analytical of factors determinants of happiness at work case study on PT. PLN (persero) region Suluttenggo, Sulawesi, Indonesia. European Journal of Business and Management, 7 (8), 9-17.

Karkoulian, Silva, Srour, Jordan, Sinan, Tala (2016). A gender perspective on work-life balance, perceived stress and locus of control. Journal of Business Research, 69, 4918-4923.

Korkmaz, Oya, \& Erdoğan, Evrim (2014). İş yaşam dengesinin örgütsel bağlılık ve çalışan memnuniyetine etkisi. Ege Academic Review, 14 (4), 541-557. DOI: 10.21121/ eab.2014418011.
Kyvik, Svein, \& Olsen, Terje B. (2008). Does the aging of tenured academic staff affect the research performance of universities?. Scientometrics, 76(3), 439-455. DOI: 10.1007/ s11192-007-1767-z.

Lyubomirsky, Sonja, King, Laura, Diener, Ed (2005). The benefits of frequent positive affect: does happiness lead to success? Psychological Bulletin, 131 (6), 803-855. DOI: 10.1037/00332909.131.6.803.

Masron, Tajul, A., Ahmad, Zamri \& Rahim, Norizan B. (2012). Key performance indicators vs key intangible performance among academic staff: A case study of a public university in Malaysia. Procedia-Social and Behavioral Sciences, 56, 494-503. DOI: 10.1016/j.sbspro.2012.09.681.

Maxwell, Scott E. \& Cole, David A. (2007). Bias in cross-sectional analyses of longitudinal mediation. Psychological Methods, 12(1), 23-44. DOI: 10.1037/1082-989X.12.1.23.

Miller, Cindy S. (2008). Meaningful work over the life course (Unpublished doctoral thesis). Fielding Graduate University, USA.

Mustafayeva, Sabin, \& Üstün, Ferda (2018). Çalışanların duygusal zeka becerilerinin iş yaşam kalitesi algıları üzerine etkisi: Türkiye ve Azerbaycan örneği. Business and Economics Research Journal, 9 (3), 665-680. DOI: 10.20409/ berj.2018.130.

Ngah, Rohana, Jusoff, Kamaruzaman, \& Rahman, Zanariah A. (2009). Emotional intelligence of Malaysian academia towards work performance. International Education Studies, 2 (2), 103-112. DOI: 10.5539/ies.v2n2p103.

Nizam, İsmail \& Kam, Chrystinne (2018). The determinants of work life balance in the event industry of Malaysia. International Journal of Management, Accounting and Economics, 5 (3), 141-168.

Numbers of Lecturers (2019).Retrieved from https://istatistik. yok.gov.tr/ Accessed February 5, 2020.

Olcay, Gökçen, \& Bulu, Melih. (2016). Uluslararası üniversite sıralama endekslerinde Türk üniversitelerinin yeri. Yükseköğretim Dergisi, 6(2), 95-103. doi:10.2399/yod.16.003.

Ortaş, İbrahim (2018). Bilimsel yayınlar yönünden Türkiye'nin dünyadaki yeri nedir?. Retrieved from https://indigodergisi.com/2018/07/bilimsel-yayinlar-turkiye-yeri/. Accessed December 15, 2019.

O'Laughlin, Kristine D., Martin, Monica \& J., Ferrer, Emilio (2018). Cross-sectional analysis of longitudinal mediation processes. Multivariate Behavioral Research, 53(3), 375-402. DOI: 10.1080/00273171.2018.1454822.

Oyewobi, Luqman, O., Oke, Ayodeji E., Adeneye, Toyin D. \& Jimoh, Richard A. (2019). Influence of organizational commitment on work-life balance and organizational performance of female construction professionals. Engineering, Construction and Architectural Management, 26 (10), 2243-2263. DOI 10.1108/ECAM-07-2018-0277.

Quick, James C., \& Quick, Jonathan D. (2004). Healthy, happy, productive work: A leadership challenge. Organizational Dynamics, 33 (4), 329-337. https://doi.org/10.1016/j.orgdyn.2004.09.001. 
Rego, Armenio \& Cunha, Miguel P. (2008). Authentizotic climates and employee happiness: pathways to individual performance? Journal of Business Research, 61, 739-752. https://doi.org/10.1016/j.jbusres.2007.08.003.

Rego, Armenio, Ribeiro, Neuza, \& Cunha, Miguel P. (2010). Perceptions of organizational virtuousness and happiness as predictors of organizational citizenship behaviors. Journal of Business Ethics, 93, 215-235. DOI 10.1007/s10551-0090197-7.

Rowley, Jennifer (1996). Motivation and academic staff in higher education. Quality Assurance in Education, 4(3). 11-16. https://doi.org/10.1108/09684889610125814.

Ryan, Richard M., Deci, Edward L. (2001). On happiness and human potentials: A review of research on hedonic and eudemonic well-being. Annual Review Psychology, 52, 141166. DOI: 10.1146/annurev.psych.52.1.141.

Salovey, Peter, \& Mayer, John D. (1990). Emotional intelligence. Imagination, Cognition and Personality, 9, 185-211. https:// doi.org/10.2190/DUGG-P24E-52WK-6CDG.

Saydan, Reha (2008). Üniversite öğrencilerinin öğretim elemanlarından kalite beklentileri: yüzüncü yıl üniversitesi iỉBF örneği. Gazi Üniversitesi Iktisadive Idari Bilimler Fakültesi Dergisi, 10(1), 63-79.

Seligman, Martin E. P., \& Csikszentmihalyi, Mihaly (2000). Positive psychology: An Introduction. American Psychologist, 55 (1), 5-14. DOI: 10.1037/0003-066X.55.1.5.

Singh, Sanjay, \& Aggarwal, Yogita. (2018). Happiness at work scale: Construction and psychometric validation of a measure using mixed method approach. Journal of Happiness Studies, 19, 1439-1463. https://doi.org/10.1007/s10902017-9882-x.

Slaski, Mark, Cartright, Susan (2003). Emotional intelligence training and its implications for stress, health and performance. Stress and Health, 19, 233-239. https://doi. org/10.1002/smi.979.

Soomro, Aqeel A., Breitenecker, Robert J., \& Shah, Syed. A. M. (2018). Relation of work-life balance, work-family conflict and family-work conflict with the employee performance-moderating role of job satisfaction. South Asian Journal of Business Studies, 7 (1), 129-146. DOI 10.1108/ SAJBS-02-2017-0018.

Stock, R. M. (2016). Understanding the Relationship between Frontline Employee Bore-out and Customer Orientation. Journal of Business Research. 69, 4269-4268.
Tadic, Maja, Bakker, Arnold B. \& Oerlemans, Wido G. M. (2013). Work happiness among teachers: a day reconstruction study on the role of self-concordance. Journal of School Psychology, 51, 735-750. https://doi.org/10.1016/j. jsp.2013.07.002.

Talukder, A.K.M., Vickers, Margaret, \& Khan, Aila. (2018). Supervisor support and work-life balance impacts on job performance in the Australian financial sector. Personnel Review, 47 (3), 727-744. DOI 10.1108/PR-12-2016-0314.

Tarhan, Nevzat (2014). Duyguların Psikolojisi. Ministry of Culture Publishing, İstanbul. ISBN: 9786050823691.

Tischler, Len, Biberman, Jerry, \& McKeage, Robert. (2002). Linking emotional intelligence, spirituality and workplace performance. Journal of Managerial Psychology, 17 (3), 203218. DOI 10.1108/02683940210423114.

Uyar, Başar (2018). Ranking chemical engineering departments in Turkey based on academic performance. Yükseköğretim Dergisi, 8(2), 125-132. doi:10.2399/yod.17.019.

Ünal, Ali F. (2017). Türkiye yükseköğretim alanında rakip kurumsal mantıklar: akademik performans kriterlerinde çeşitlilik ve yayın üretkenliği üzerine etkisi. Amme İdaresi Dergisi, 50(4), 83-114. ISSN: 1300-1795.

Wong, Chi-Sum \& Law, Kenneth S. (2002). The effects of leader and follower emotional intelligence on performance and attitude: An exploratory study. The Leadership Quarterly, 13, 243-274. https://doi.org/10.1016/S1048-9843(02)00099-1.

Wood, Fiona (1990). Factors influencing research performance of university academic staff. Higher Education, 19, 81-100.

Wright, Thomas. A. (2003). Positive organizational behavior: An idea whose time has truly come. Journal of Organizational Behavior, 24, 437-442. DOI: 10.1002/job.19.

Wright, Thomas. A.\& Cropanzano, Rusell (1997). Well-being, satisfaction and job performance: another look at the happy / productive worker thesis. Academy of Management Proceedings. https://doi.org/10.5465/ambpp.1997.4988986.

Wright, Thomas A. \& Cropanzano, Russell (2007). The happy / productive worker thesis revisited. Research in Personnel and Human Resources Management, 26, 269-307. DOI: 10.1016/S0742-7301(07)26006-2.

Yılmaz, Hüseyin (2013). Yüksek Performans Organizasyonu Liderlik Kültür ve Tasarım. Beta Publishing, İstanbul.

Yusoff, R., Khan, Anwar \& Azam, Kamran (2013). Job stress, performance and emotional intelligence in academia. Journal of Basic and Applied Scientific Research, 3(6), 1-8. 